This is the version of the chapter accepted for publication in Cohen, David, Tan, Kevin Y.L. and Nabahan, Aviva, (eds.), Human Rights and ASEAN: Indonesian and International Perspectives. Singapore: World Scientific, pp. 85-98.

https://doi.org/10.1142/9789811229503_0006

Accepted version downloaded from SOAS Research Online: http://eprints.soas.ac.uk/32498

Re-use is subject to the publisher's terms and conditions

\title{
One Vision, Three Communities? \\ Reflections on Human Rights in ASEAN's Community Blueprints
}

\section{By Michelle Staggs Kelsall}

\section{Introduction: In Search of Community in Southeast Asia}

In 2015, the Association of Southeast Asian Nations ('ASEAN') reached another major milestone toward regional integration by formally establishing the ASEAN Community ('AC'). The AC brought with it a renewed agreement from ASEAN Member States ('AMS') to implement ASEAN's common vision of a 'politically cohesive, economically integrated, socially responsible and truly rules-based, people-oriented, people-centred ASEAN'. The newly adopted ASEAN Economic, Socio-Cultural, and Political Security Blueprints (2015-2025) provided an ambitious agenda for ASEAN to achieve these ends. ${ }^{2}$

Five years into its establishment, ASEAN faces a number of significant challenges to its claims of creating an integrated regional community. In Myanmar, credible allegations that armed forces are committing systematic and widespread human rights violations against Rohingya Muslims persist and are now incontrovertible. This denial of the fundamental human rights of the Rohingya is being further entrenched by the government's ongoing failure to repeal discriminatory laws denying Rohingya citizenship and prohibiting them from claiming to have rights in the first place. ${ }^{3}$ In the Philippines, the war on drugs launched by the Duterte administration since 2016 has been characterized by police obtaining carte blanche authority to kill suspected drug users and drug dealers. This is despite the Philippines having ratified the International Covenant on Civil and Political Rights (prohibiting extrajudicial killings) over thirty years ago. The constitutionality of the war on drugs currently forms the basis of a case before the country's Supreme Court. ${ }^{4}$ And as Viet

${ }^{1}$ Kuala Lumpur Declaration on ASEAN 2025: Forging Abead Together, preamble, at paragraph 6. (Jakarta: The ASEAN Secretariat, 2015) Available online at: < http://www.asean.org/storage/2015/12/ASEAN-2025-Forging-Ahead-Together-final.pdf> accessed 11 April 2016. (Hereafter 'Forging Ahead').

2Ibid., at pp. 19-103.

${ }^{3}$ See UNHRC, A/HRC/42/CRP.5 'Detailed findings of the Independent International Fact-finding Mission on Myanmar' (16 September 2019), 17-67. See also, UNHRC, A/HRC/39/CRP.2 para. 491. Section 347 of the 2008 Constitution of Myanmar stipulates that the Government is to 'guarantee any person to enjoy equal rights before the law and shall equally provide legal protection'. The reality is that rights, such as the right to access education, health care and livelihood activities, are linked to citizenship. Most notably, constitutional provisions link land ownership with citizenship, giving rise to a well-founded fear that Rohingya can be legally dispossessed of their lands without confirmation of citizenship.

${ }^{4}$ The International Criminal Court's prosecutor, Fatou Bensouda, has undertaken to begin a preliminary examination into the killings in President Rodrigo Duterte's 'bloody war on drugs'. See 'ICC set to conclude preliminary exam on drug war' Helen Flores, Philippines Star (7 December 2019) available online at: https://www.philstar.com/headlines/2019/12/07/1974992/icc-set-concludepreliminary-exam-drug-war

[Accessed 31 December 2019]. On the constitutional proceedings, see: National Police Commission, National Headquarters Philippines, National Police - Office of the Chief, PNP, Command Memorandum Circular No.16 - 2016 'PNP Anti-Illegal Drugs Campaign Plan Project: "Double Barrel"” available online at: http://didm.pnp.gov.ph/Command\%20Memorandum\%20Circulars/CMC\%20201616\%20PNP $\% 20$ ANTI- 
Nam takes the chair of the regional association, ongoing tensions in the South China Sea continue to divide ASEAN Member States between those who wish to take a strong stance against China's economic claims in the region (and the socio-environmental consequences of those claims), and those who prefer to maintain close ties with their Far East partner in order to secure ongoing trade and investment. ${ }^{5}$ Despite continuing to claim to be rules-based and people-oriented, commentators question the extent to which AMS prefer to govern utilizing rule by law, rather than rule of law, and the implications this has both for AMS' diverse populations and the future of Southeast Asia as a regional bloc.

Rather than critiquing the veracity of this claim or considering whether ASEAN is, in fact, a rules-based community, this chapter instead considers ASEAN's community blueprints as the starting point for an analysis of what kind of community ASEAN itself envisages, and what role conceives human rights playing within it. Utilizing the ASEAN community blueprints as an analytical frame through which to interpret AMS' commitments to fulfil their obligations under the ASEAN Charter, it asks: how do the community blueprints envisage that ASEAN Member States (jointly and severally) interpret their obligation to promote and protect human rights (as well as promote social justice) under the ASEAN Charter? ${ }^{6}$ Conversely, to what extent (if at all) are human rights protections considered part of the AC's integration process? And what are the implications of this (non-)consideration for the future of human rights protections in regional integration? It is to these questions that I now turn.

\section{Myopic Vision, Small Steps: Non-Interference and Political Independence as the Core of the ASEAN Political Security Community Blueprint}

Originally established as a regional association to ward off the twin dangers of Great Power domination and communist insurgency, ASEAN was not envisaged as a stand-alone international organization. The Treaty of Amity and Cooperation, one of the earliest treaties ratified by AMS, promised just that: friendship and collaboration amongst a region of diverse governments. At the

ILLEGAL $\% 20$ DRUGS $\% 20$ CAMPAIGN $\% 20$ PLAN $\% 20 \%$ E2\%80\%93\%20PROJECT $\% 20$ DOUBL E\%20BARREL.pdf and analysis provided at 'Tokhang documents prove drug war caused cops to kill suspects - FLAG', Lian Buan, Rappler (23 October 2019), available online at: https://www.rappler.com/nation/243230-flag-says-tokhang-documents-prove-drug-war-causedcops-kill-suspects [Both accessed 31 December 2019].

5What Does ASEAN's Evolving Approach to the South China Sea Issue Mean for Vietnam?', Rajeswari Pillai Rajagopalan, The Diplomat (1 November, 2019), available online at: https://thediplomat.com/2019/11/what-does-aseans-evolving-approach-to-the-south-china-seaissue-mean-for-vietnam/ [Accessed 31 December 2019]. See also: Nguyen Thi Lan Anh, 'The South China Sea Award: Legal Implications for Vietnam' (2016) 38(3) Contemporary Southeast Asia: A Journal of International and Strategic Affairs 369; Irene Chan and Mingjiang Li, New Chinese Leadership, New Policy in the South China Sea Dispute?' (2015) 20 Journal of Chinese Political Science 35.

${ }^{6}$ Charter of the Association of Southeast Asian Nations, adopted in Singapore on 20 November 2007 ('ASEAN Charter'). Article 2 of the ASEAN Charter reads in relevant parts:

'(1) In pursuit of the Purposes stated in Article 1, ASEAN and its Member States reaffirm and adhere to the fundamental principles contained in the declarations, agreements, conventions, concords and other treaties of ASEAN.

(2) ASEAN and its Member States shall act in accordance with the following Principles:...

(i) respect for fundamental freedoms, the promotion and protection of human rights, and the promotion of social justice;...' 
time, none of the states were committed to granting ASEAN supranational authority. ${ }^{7}$ Instead, it was signed by states 'anxious to promote regional peace and stability through abiding respect for justice and the rule of law and enhancing regional resilience in their relations'. ${ }^{8}$ The Treaty itself spoke of strengthening 'traditional cultural and historical ties through friendship and good neighbourliness' and facilitating 'contact and intercourse among their peoples' (amity). 'At same time, the five founding members of ASEAN sought to promote active cooperation in the economic, social, technical, scientific and administrative fields as well as in common aspirations of international peace and stability; accelerated economic growth; and to prevent threats to international security (cooperation). ${ }^{10}$ There was no mention of a common, institutionalized international association, nor did the Treaty gesture toward the creation of one. This was perhaps most strongly emphasized in the clause pertaining to the official language of the instrument, which was to be all the official languages of the High Contracting Parties, all of which were to be equally authoritative. ${ }^{11}$

The 2007 ASEAN Charter sought to break with the past and to confer upon ASEAN international legal personality. ${ }^{12}$ Yet unlike other regional organizations, the clause pertaining to legal personality does little to clarify the extent to which ASEAN can claim to have powers to carry out its functions and duties as agreed by AMS independently of those member states. ${ }^{13}$ In this respect, at least three possibilities exist as a matter of international law. According to the doctrine of attributed powers, ASEAN would only work on the basis of powers specifically attributed to the organization and would not in any way restrict the sovereignty of its member states. ${ }^{14}$ Conversely, under the doctrine of implied powers (which draws from federalist systems), treaty rules should be interpreted to guarantee their fullest effect, and therefore ASEAN should be afforded powers, although not expressly provided in the Charter, that are essential to the performance of its duties. This doctrine was relied upon by the International Court of Justice as to the powers conferred on the United Nations in its classic opinion in the Reparations for Injury case. ${ }^{15}$ Finally, a third possibility would be to claim that ASEAN has inherent powers to perform all acts needed to attain the aims of the association, not due to any specific source of organizational

${ }^{7}$ Treaty of Amity and Cooperation, adopted 24 February 1976, Jakarta, Indonesia.

8Ibid, Preamble, paragraph 2.

IIbid. Article 3.

10Ibid., Articles 4-8.

${ }^{11}$ Ibid., Article 21.

12ASEAN Charter, Article 3 states: 'ASEAN, as an intergovernmental body, is hereby conferred legal personality'.

${ }^{13}$ Compare as examples Article 282 of the Treaty of the European Community, Official Journal C 325, 24 December 2002, which provides that the EU has the extensive legal capacity afforded to legal persons in accordance with Member States' domestic laws; Article 24 of the Constitutive Act of the African Union (adopted on 11 July, 2000) which confers legal capacity on the African Union in accordance with the laws of its Member States; and Article 103 of the Charter of the Organization of American States (1948) in which the OAS has 'legal capacity as may be necessary for the exercise of its functions and fulfilment of its purposes'.

${ }^{14}$ See in particular, the Advisory Opinion on the ILO [1926], PCIJ Series B, no.13, and Jurisdiction of the European Commission of the Damube between Galatz and Braila, Advisory Opinion [1926], PCIJ Series B., no.14, especially at 64. See also the dissenting opinion of Judge Hackworth Reparations for Injuries Suffered in the Service of the United Nations, Advisory Opinion, [1949] ICJ Rep 174, at 198-9.

${ }_{15}^{15}$ ee Reparations for Injuries Suffered in the Service of the United Nations, Advisory Opinion, [1949] ICJ Rep 174, 12. Note also: Interpretation of the Greco-Turkish Agreement of December 1st 1926, PCIJ [1928] PCIJ, Ser. B., no.16. 
power but simply because they inhere in it as an organization. As such, anything which is not prohibited (attributive) is deemed legally valid or permitted (implied). ${ }^{16}$

The ASEAN Political-Security Blueprint ('APSC') suggests that ASEAN is to function largely at the behest of AMS and in keeping with the doctrine of attributed powers. Although it gestures toward AMS possessing 'shared values' and promoting legal norms to institutionalize a rules-based community, it provides no detail as to what these values are or how they are shared. This is seemingly a lost opportunity through which AMS could have invoked the ASEAN Human Rights Declaration as the basis for these values. Additionally, far from providing ASEAN with a wide ambit of powers through which to determine the constitutional basis for regional integration, the blueprint instead focuses largely on the Secretariat's technocratic functions. Although promising to 'elevate ASEAN political and security cooperation to an even higher level' ${ }^{17}$, ASEAN is not empowered with the means or methods through which to do so. The primary basis upon which ASEAN exercises its political-security functions is the ASEAN Charter and through the promotion of the shared values contained therein, including human rights. Yet the Charter itself largely constitutionalized ASEAN as an administrative body, providing no avenues through which the association's capacity to determine regional issues could take place outside of inter-ministerial consensus. In this respect, the Charter does not contain provisions analogous to the Charter of Fundamental Rights of the European Union or the African Charter on Human and Peoples Rights, which reiterate the stand-alone rights of individuals and peoples within those regions as distinct from states.

Hence, despite attempting to break with the past in 2007, both the Charter and the APSC would seem to reiterate and entrench ASEAN's longstanding tradition of non-interference and the 'ASEAN way.' Rather than delineating the basis upon which regional integration might begin to conceive of a supranational community identity distinct from the individual imagined communities of each nation state, the APSC instead reiterates the fragmentation within that community by vesting decision-making authority within each AMS. The whole is, in effect, not greater than the sum of its parts. Yet at the same time, the APSC attempts to invoke political leadership as essentially being agreed through a process of leadership from beneath (if not below): rather than ASEAN dictating what AMS should do, ASEAN's leadership is very much located near the heart of its members, a kind of horizontal embeddedness that provides for interministerial avenues of cooperation and examples of good conduct, rather than rational assessment of adherence to normative commitments and protection of rights. Hence, integration is conceived in similar terms to that of ancient Chinese philosopher, Lao-Tsu: the art of leadership is seemingly at its best when the art conceals the art.

\section{Between the Individual and the Collective: ASEAN as Regional Interlocutor in the ASEAN Socio-Cultural Community Blueprint}

Unlike the APSC, the 2015 ASEAN Socio-Cultural Community Blueprint ('ASCC') conceives of ASEAN Community primarily in terms of its peoples: the term 'people' is used thirty-six times over thirty-four pages. ${ }^{18}$ Rather than framing a normative commitment toward human rights in terms of the territorial integrity and political security of AMS, the ASCC instead frames rights as representing ASEAN's commitment to provide better economic and social opportunities for the

${ }^{16} \mathrm{On}$ this theory, see in particular, Jan Klabbers, An Introduction to International Organizations Law (CUP $3^{\text {rd }}$ Edn 2015), 41- 69.

${ }^{17}$ ASEAN Political and Security Blueprint, paragraph 3.

${ }^{18}$ ASEAN Socio-Cultural Community Blueprint (ASEAN Secretariat, Jakarta, November 2015). 
region's population. The document itself veers between language that argues for this commitment in terms of economic development (on the one hand) ${ }^{19}$ and ensuring that those who are lifted from poverty in the region include - and indeed, focus on -- marginalized and vulnerable populations, on the other. ${ }^{20}$

Several scholars within ASEAN have questioned the merits of the ASCC on the grounds that the approach ASEAN adopts is somewhat misguided. Farish Noor, for instance, questions the multiple traps associated with an unreconstructed nostalgia and simplistic essentialism in both the histories and geographies of Southeast Asia that have been mapped on to the ASEAN blueprints. ${ }^{21}$ For Noor, part of the problem with coming to grips with the subaltern as determined through the ASCC and other forms of official documentation, is that so much of what informs Southeast Asians' perspective of themselves has been constructed utilizing the tools and vocabularies of modernity. ${ }^{22}$ This perspective presupposes that the starting point of any investigation is the South-east Asian nation state, which 'confirms the fact that we are all inheritors of that epistemology that dates back to Westphalia, modern Europe and of course colonialism'. ${ }^{23}$ Noor argues for an interrogation of the discursive economy of modernity constructed in the ASCC and elsewhere and suggests that only by upsetting some of the forms of binary logic that is at work in these documents can we move toward process-driven agreement on identity formation. As Noor notes:

'It entails also having to understand that while Southeast Asia - even as a political construct - undoubtedly exists, there are also other ways to imagine our region and understand how individuals feel a sense of belonging to it. ${ }^{24}$

Similarly, Vittit Muntabhorn questions the substantive impact that ASEAN peoples can have on the regional agenda formulated by ASEAN, in light of centralized bureaucratic processes which do not necessarily permit civil society to act as the check and balance on democracy it seeks to be. ${ }^{25}$ Although largely adopting an institutionalist perspective which does not go so far as to question the normative commitments of ASEAN per se, Muntarbhorn notes that the challenge is to focus those commitments on substantive care that is centrally located in the overlapping and contested communities which comprise ASEAN, rather than in any monocentric, regional structure which claims to be representing the same. ${ }^{26}$

Hence, the ASCC seems at once to be locked into a programme of big governance (replacing big government with a platform of unified, regional development, largely aligned with the United Nations' sustainable development goals) while at the same time gesturing toward the

${ }^{19}$ Ibid., 10-12. Note in particular, the links created between the protection and promotion of human rights and development, establishing a clear nexus between the two in keeping with the mainstream discourse on the same.

20Ibid., 8-20.

${ }^{21}$ Farish A. Noor, 'Where do we Begin? Reclaiming and Reviving Southeast Asia's Shared Histories and Geographies' in Aileen Baviera and Larry Maramis (eds) Building ASEAN Community: PoliticalSecurity and Socio-cultural Reflections (Economic Research Institute for ASEAN and East Asia, 2017) 247. ${ }^{22}$ One can of course argue that the term 'Southeast Asian' itself is a modern construct. See in particular, Benedict Anderson,

${ }^{23}$ Supra, note 24, at 251.

${ }^{24}$ Ibid., 253.

25Vitit Muntarbhorn, 'Enlarging the Space for the People: Whither Human Rights and Governance in ASEAN?' in Aileen Baviera and Larry Maramis (eds) Building ASEAN Community: Political-Security and Socio-cultural Reflections (Economic Research Institute for ASEAN and East Asia, 2017) 208.

26Ibid., 218. 
multiplicity of geographies and histories to which the region gives rise and must continue to respect. ${ }^{27}$ Somewhat ironically, what emerges is a blueprint that at once mimics or reiterates the very forms of authority ASEAN was originally established to fight against (namely, external powers whose programmes are now largely administered through the United Nations, the World Bank and the International Monetary Fund), while claiming to do so in the name of the peoples AMS find the most threatening to the region today (namely, subaltern communities including indigenous persons, ethnic minorities and women - undoubtedly the largest 'vulnerable population' of them all).

\section{Economic Integration at What Cost? Business as Usual in ASEAN}

Conversely, to what extent (if at all) are human rights protections considered part of the AC's economic integration process? What are the implications of this (non-)consideration for the future of human rights protections in regional integration more broadly?

Finally, this Chapter turns to consider the ASEAN Economic Community Blueprint. Economic integration has remained at the cornerstone of AMS' efforts toward integration through ASEAN for the better part of the last twenty years, if not before. The rationale for economic integration is, however, somewhat opaque and dependent upon which AMS is being considered. ASEAN itself claims that economic integration should be assessed based on: (1) a highly cohesive and integrated economy (if not the creation of a single market and production base); ${ }^{28}$ (2) the competitiveness of the region as a whole (measured in terms of the combined GDP growth of AMS against that of other states and regions); (3) the extent to which this integration amounts equitable economic development amongst AMS; and (4) the extent to which ASEAN has become integrated into the global economy by establishing free trade, and comprehensive economic partnership, agreements with partners in the Asia-Pacific and beyond. ${ }^{29}$ Human rights plays little or no role in the establishment of the AEC, which prioritizes intellectual property and consumer rights, but otherwise focuses on macroeconomic indicators to ascertain progress toward ASEAN's goals. $^{30}$

Unlike the APSC and the ASCC, the language utilized in the AEC Blueprint re-inscribes Southeast Asia's vision of regional community as primarily determined through the free flow of labour and capital. 'Community', in this instance, is less about what unites ASEAN's peoples or allows for the protection of AMS' borders but instead what provides for the movement of goods and services across borders. The view of the economies of Southeast Asia as espoused through this blueprint appears largely to be neoliberal in orientation. Much like the Geneva School of international lawyers and economists that have embraced this orientation since at least the middle of last century, the AEC envisages ASEAN designing institutions not to liberate markets but to encase them, to inoculate markets against democracy and to create a framework which will contain oft-irrational human behavior.

Yet despite framing ASEAN's response to globalization using a vernacular embracing this rational response to growing international and inter-regional competition, the AEC Blueprint itself remains largely superficial in its attempt to circumscribe Southeast Asia's economic landscape toward neoliberal ends. Lee Jones has argued, for instance, that the failure of the AEC to achieve significant progress toward its goals in the 2009-2015 period can be explained through the inability

${ }^{27}$ Ibid., at paragraphs 10, 13(ii), 13(viii), D.4, D.5 and E.3

${ }^{28}$ ASEAN Economic Community Blueprint 2025 (ASEAN Secretariat, Jakarta, November 2015), 1

${ }^{29}$ Ibid. at 'E. A Global ASEAN' (paragraphs 79-80).

${ }^{30}$ Ibid., paragraphs 30 and 52, at 13 and 24. 
of ASEAN to grapple with the shifting dynamics of political economy in each AMS. ${ }^{31}$ For Jones, although the AEC Blueprint describes the wish-list of neoliberal technocrats at the helm of the integration process, it does very little to depict or determine a roadmap for which structural and readjustment costs that need to be borne by significant sectors of the business community within AMS can be distributed between governments to obtain integration as hoped. ${ }^{32}$ Additionally, the Blueprint does little to determine how endemic corrupt practices within AMS can be eradicated in order to achieve these goals. Hence, although the AEC Blueprint claims to be the foundation of the integration process, it signals less integration and more a lack of socio-political cohesion than it does any agreed platform for policy coherence. As Jones has noted, 'For accurate analysis, we must open up the 'black box' of the state and attend to the socio-political forces shaping how state power is actually used. ${ }^{33}$

Hence, although seemingly conceived as a threat to the state's authority, the lack of consideration of human rights does more to damage the hopes contained within the AEC Blueprint than acknowledging them might at first seem to do. Quinn Slobodian has argued, for instance, that the 'human right of capital flight' animating the neoliberal project from the hallowed halls of the International Chamber of Commerce in Geneva was in part a means through which economists and lawyers in Europe maintained the legitimacy of capitalism and the world economic order they were building to support it. ${ }^{34}$ The seeming lack of a linkage between individual human rights and economic integration suggests that what ASEAN envisages as an integrated economic community may as yet be less rules-bound than the APSC would have us believe. Yet at the same time, nor is the AEC envisaging a people-oriented ASEAN, in which autochthonous understandings of rights take hold that further empower ASEAN's many collectivities. Rather, what the AEC seems to want to achieve is instead, business as usual in ASEAN, through which individual AMS remain opaque as to the real motivations and desires for pursuing integrative ends.

\section{Conclusion}

The chapter has argued that fundamental tensions exist between ASEAN's commitments toward human rights protection and promotion and the imagined communities envisaged within ASEAN's three blueprints. ${ }^{35}$ Drawing from the administrative vernacular contained in these documents, ${ }^{36}$ it then argued that international law, as envisaged by the community blueprints, is said to protect and promote human rights in three fundamentally distinct ways.

First, under the ASEAN Political and Security Blueprint, international law is construed as protecting human rights in order to ensure the ongoing political security and territorial integrity of AMS. Viewed from this perspective, the ASEAN Charter primarily safeguards human rights only insofar as those rights maintain international peace and security within the region. Next, under

${ }^{31}$ Lee Jones, 'Explaining the failure of the ASEAN Economic Community: the primacy of domestic political economy' (2016) 29(5) The Pacific Review 647, 666.

32Ibid.

33Ibid., 666.

${ }^{34}$ Quinn Slobodian, Globalists: The End of Empire and the Birth of Neoliberalism (Harvard University Press, 2018), 134.

${ }^{35}$ Here, I am self-consciously gesturing toward the work of Benedict Anderson on the origin and spread of nationalism, and that author's view of the nation-state as understood in Southeast Asia. See Benedict Anderson, Imagined Communities: Reflections on the Origin and Spread of Nationalism (Verso, 1983) [Hereafter, Anderson (1983)]. See also Benedict Anderson, The Spectre of Comparisons: Nationalism, Southeast Asia and the World (Verso, 1998).

${ }^{36} \mathrm{On}$ the birth of administrative vernaculars see Anderson (1983), 41. 
the ASEAN Socio-Cultural Community Blueprint, international law protects human rights for and on behalf of the ASEAN peoples, both individually and collectively. Adopting an intersectional approach to human rights protection, the Socio-Cultural Community Blueprint attempts to institutionalise ASEAN Member States' commitment to pursue to needs of Southeast Asia's subaltern communities, variously construed in terms of their race, gender, class and abilities. Finally, under the ASEAN Economic Community Blueprint, international law is conceived as protecting rights only insofar as those rights continue to facilitate the free flow of goods and services across territorial borders within ASEAN. In this final respect, international law is largely construed as the private international law of commerce (as opposed to the public international law of states). As such, despite their capacity to entrench the neoliberal understanding of the global economy that ASEAN attempts to espouse, human rights do not exist in the ASEAN economic community: only intellectual property and consumer rights are mentioned as being worthy of protection at all.

What emerges from this reading of the instruments is that, while ASEAN governments claim to be constructing one community, based on one vision and one identity, the many possibilities for community as contained in ASEAN's blueprints do not legitimate or authorise this claim. Far from resolving the schisms both amongst ASEAN's diverse communities and within Southeast Asia, the blueprints only further entrench differences regarding how the ASEAN Charter might yet ensure a constitutional commitment toward a protecting human rights or securing the welfare of their peoples. In so doing, they reflect ongoing disagreement both within and between ASEAN governments as to what the ASEAN community is and what it should become. Seen in this light, the calls to act as 'one ASEAN' and 'one community' are less a show of authoritarian power (as is often assumed by civil society operating within ASEAN) and more a plea for a communitarian impulse to take hold. ASEAN is, in many respects, revealing as much about what continues to be a fragile hope for the region as it is any concrete agreement as to how its Member States intend to achieve it. 